\title{
EDUKASI PEDOMAN GIZI SEIMBANG (PGS) TERHADAP PENGETAHUAN DAN SIKAP SISWA SMP NEGERI 1 BARRU
}

\author{
Abdullah Tamrin ${ }^{1}$, Retno Sri Lestari ${ }^{1}$, Yusdevitasari ${ }^{2}$ \\ ${ }^{1}$ Jurusan Gizi, Politeknik Kesehatan Kemenkes Makassar \\ ${ }^{2}$ Alumni Jurusan Gizi, Politeknik Kesehatan Kemenkes Makassar \\ *)Email : yusdevitasari@gmail.com
}

\begin{abstract}
One of the efforts to increase knowledge is by providing education about health, especially about nutrition. Education of nutrition is an activity to convey a health message to the community or group in order to give a direct impact their knowledge and attitude development. This study aims to find out the effect of education of balanced nutrition guidelines towards students' knowledge and attitude of SMP Negeri 1 Barru. The type of research used was a pre-experimental study with design of one group pre-test and post-test design conducted in SMP Negeri 1 Barru by involving 250 students as samples at the grade VII and VIII which was obtained by using simple random sampling. The sampling process was conducted on May 15 May 17 2019. The results of the research conducted at SMP Negeri 1 Barru showed that students' knowledge before being given good nutrition knowledge was (60\%), while after being given education of nutrition, it increased to good $(80.4 \%)$ by using the Wilcoxon statistical test and obtained a value $(p=0,000)$ which means that there is an effect of education of nutrition towards students' knowledge. The students' attitude before being given education of nutrition was (32\%) as students at the good level, while after being given education of nutrition, it increased to good (64.8\%) by using the Wilcoxon statistical test and obtained a value $(p=0,000)$ which means there is an effect of education of nutrition towards students' attitude. The level of students' nutrition knowledge and attitudes increased after education of nutrition was conducted and there was a significant effect indicated by the value of $p=0,000(p<0.05)$.
\end{abstract}

Keywords : Education of nutrition, knowledge, attitute

\section{PENDAHULUAN}

Edukasi gizi adalah pendekatan edukatif untuk meningkatkan pengetahuan dan sikap remaja terhadap gizi. Semakin tinggi pengetahuan gizi akan berpengaruh terhadap sikap dan perilaku konsumsi makanan (Claire, 2010).

Hasil penelitian Jan S et al., (2009) di New Jersey tentang program pendidikan sekolah untuk mempromosikan makanan yang sehat dan olahraga, mendapatkan hasil bahwa terjadi peningkatan pengetahuan anak SD setelah mendapatkan program pendidikan. Menurut penelitian Nuryanto et al., (2014) menunjukkan bahwa ada pengaruh pendidikan gizi terhadap pengetahuan anak SD tentang gizi anak sekolah, sebelum diberikan edukasi adalah $66,45 \%$ meningkat menjadi $71,61 \%$.

Hasil penelitian yang dilakukan Maulana et al., (2012), menunjukkan bahwa tingkat pengetahuan anak tentang gizi kurang yaitu 53,7\%. Hasil penelitian Afdal (2011), tentang pengetahuan gizi 
pada siswa di SMPN 1 Sawahlunto juga masih kurang yaitu $51,90 \%$.

Hasil penelitian Achmad et al., (2014) pada siswa SMA Negeri 10 Makassar menyatakan bahwa 56\% yang masih kurang mengonsumsi buah dan sayur. Hasil penelitian Suryanti (2012), pada remaja di SMAN 13 Makassar menunjukkan bahwa sebanyak 57,9\% penerapan gizi seimbang masih kurang. Sedangkan, hasil penelitian Sari (2014), pada siswa di MTs Pembangunan UIN Syarif Hidayatullah Jakarta diketahui bahwa jenis makanan yang dikonsumsi remaja tidak sesuai dengan Pedoman Gizi Seimbang (PGS) yaitu 62,5\%, frekuensi makan remaja juga tidak sesuai dengan Pedoman Gizi Seimbang yaitu 85,4\% dan remaja yang memiliki pola hidup bersih sesuai dengan Pedoman Gizi Seimbang sebanyak 56,3\%. Jadi, hampir keseluruhan remaja tidak sesuai dalam mempraktekkan pesan-pesan yang terkandung dalam Pedoman Gizi Seimbang.

Arisman (2010) menyebutkan bahwa salah satu penyebab masalah gizi dikarenakan minimnya pengetahuan akan gizi yang kemudian dapat menyebabkan kesalahan dalam memilih makanan. Untuk memperbaiki asupan gizi dan status gizi remaja antara lain perlu upaya peningkatan pengetahuan gizi melalui pendidikan gizi. Pendidikan gizi akan meningkatkan pengetahuan gizi anak dan akan membantu sikap anak sehingga dapat mempengaruhi kebiasaan anak dalam memilih makanan dan snack yang menyehatkan (Healthy People, 2010).

Berdasarkan hal tersebut, peneliti tertarik untuk melakukan penelitian tentang pengaruh edukasi Pedoman Gizi Seimbang (PGS) terhadap pengetahuan dan sikap siswa di SMP Negeri 1 Barru.

\section{METODE}

\section{Desain, tempat dan waktu}

Desain penelitian yang digunakan adalah studi pra eksperimen dengan rancangan one group pre-test dan post-test design. Penelitian ini dilaksanakan di SMP Negeri 1 Barru pada bulan Mei 2019.

Jumlah dan cara pengambilan subjek

Populasi dari penelitian ini adalah adalah siswa kelas VII dan VIII SMP Negeri 1 Barru yang berjumlah 529 siswa. Sedangkan subjek pada penelitian ini adalah sebanyak 250 orang yang dipilih secara acak menggunakan metode simple random sampling

\section{Jenis dan Cara Pengumpulan Data}

Jenis penelitian yang digunakan adalah studi pra eksperimen dengan rancangan one group pre-test dan post-test design dengan cara pengumpulan data primer meliputi pengetahuan dan sikap siswa terhadap Pedoman Gizi Seimbang (PGS) yang diperoleh dengan menyebarkan kuesioner dan data sekunder tentang gambaran lokasi penelitian atau data geografi dicatat dari dokumen pada instansi terkait di wilayah penelitian.

\section{Pengolahan dan analisis data}

Data primer meliputi pengetahuan dan sikap gizi seimbang yang diperoleh dengan menyebarkan kuesioner dan akan diolah dengan menggunakan program SPSS for Windows dengan menggunakan $U j i$ Wilcoxon untuk mengetahui pengaruh edukasi gizi terhadap pengetahuan dan sikap siswa SMP Negeri 1 Barru yang disajikan dalam bentuk tabel dan narasi dengan berpedoman pada teori-teori dan hasil penelitian yang sesuai. 


\section{HASIL}

Tabel 1

Distribusi Berdasarkan Tingkat Pengetahuan Gizi Sebelum dan Sesudah Edukasi Gizi Siswa SMP Negeri 1 Barru

\begin{tabular}{cccccc}
\hline \hline \multirow{2}{*}{ Kategori } & \multicolumn{4}{c}{ Pengetahuan Gizi } & \multirow{2}{*}{ p } \\
\cline { 2 - 4 } & \multicolumn{2}{c}{ Sebelum } & \multicolumn{2}{c}{ Sesudah } & \\
\cline { 2 - 5 } & $\mathbf{n}$ & $\mathbf{\%}$ & $\mathbf{n}$ & $\mathbf{\%}$ & \\
\hline Kurang & 14 & 5,6 & 7 & 2,8 & \\
Sedang & 86 & 34,4 & 42 & 16,8 & 0,000 \\
Baik & 150 & 60 & 201 & 80,4 & \\
\hline Total & 250 & 100 & 250 & 100 & \\
\hline
\end{tabular}

Tabel 4 menunjukkan bahwa tingkat pengetahuan gizi siswa sebelum diedukasi yaitu baik (60\%). Sedangkan, tingkat pengetahuan sesudah diedukasi gizi mengalami peningkatan yaitu baik menjadi
(80,4\%). Hasil analisis statistik menunjukkan bahwa ada pengaruh edukasi gizi terhadap pengetahuan gizi sebelum dan sesudah dengan nilai $\mathrm{p}=0,000$.

Tabel 2

Distribusi Berdasarkan Sikap Siswa Sebelum dan Sesudah Edukasi Gizi Siswa SMP Negeri 1 Barru

\begin{tabular}{ccccccc}
\hline \hline & \multicolumn{5}{c}{ Pengetahuan Gizi } & \multirow{2}{*}{$\mathbf{p}$} \\
\cline { 2 - 5 } Kategori & \multicolumn{2}{c}{ Sebelum } & Sesudah & \\
\cline { 2 - 5 } & $\mathbf{n}$ & $\mathbf{n}$ & 1 & 0,4 & \\
\hline Kurang & 10 & 64 & 87 & 34,8 & 0,000 \\
Sedang & 160 & 32 & 162 & 64,8 & \\
Baik & 80 & 100 & 250 & 100 & \\
\hline Total & 250 & & &
\end{tabular}

Berdasarkan tabel 6 menunjukkan bahwa sikap siswa sebelum diedukasi gizi yaitu kurang (4\%), sedang (64\%) dan baik (32\%). Sedangkan, sikap sesudah diedukasi gizi mengalami peningkatan yaitiu kurang $(0,4 \%)$, sedang $(34,8 \%)$ dan baik menjadi $(64,8 \%)$. Analisis statistik menunjukkan bahwa ada pengaruh edukasi gizi terhadap sikap sebelum dan sesudah dengan nilai $\mathrm{p}=$ 0,000 .

\section{PEMBAHASAN}

Mengikuti kegiatan seminar atau penyuluhan tentang kesehatan khususnya gizi termasuk salah satu usaha untuk meningkatkan pengetahuan. Penyuluhan gizi merupakan suatu kegiatan untuk menyampaikan pesan kesehatan kepada masyarakat atau kelompok dengan tujuan mempengaruhi sasaran agar bisa merubah perilakunya.

Edukasi gizi ini diberikan dua kali (dua kali dalam seminggu), dengan menggunakan metode ceramah dan tanya jawab. Materi disajikan dalam bentuk Power point dan menggunakan media laptop dan LCD.

Sejalan dengan apa yang dikatakan oleh Demitri et al., (2015), pendidikan gizi pada anak sekolah harus diberikan dengan cara dan media yang sesuai agar dapat menarik perhatian anak dan juga dapat 
memudahkan anak dalam menerima informasi mengenai gizi. Metode ceramah dan tanya jawab dipilih agar interaksi dengan siswa dapat terjadi. Sedangkan penggunaan Power point dipilih agar fokus siswa lebih dapat terkontrol dengan penggunaan gambar berwarna pada slide.

Edukasi gizi yang diberikan kepada siswa yaitu tentang 10 Pedoman Gizi Seimbang. Hasil penelitian pada tingkat pengetahuan gizi yang sebelum diberikan edukasi, tingkat pengetahuan beberapa siswa masih kurang $(5,6 \%)$ dan sedang $(34,4 \%)$ meskipun yang baik mencapai $(60 \%)$. Sedangkan, tingkat pengetahuan siswa setelah diberikan edukasi mengalami peningkatan, karena hanya $(2,8 \%)$ siswa yang pengetahuannya masih kurang, yang sedang $(16,8 \%)$ dan yang baik meningkat menjadi $(80,4 \%)$. Hal ini sejalan dengan penelitian yang dilakukan oleh Rahmiyati (2017) pada siswa SMP Negeri 35 Makassar yang mengalami peningkatan pengetahuan dari sebelumnya yang baik (42\%) menjadi (79\%) dan kurang (58\%) menjadi $(21 \%)$. Peningkatan pengetahuan gizi siswa setelah diberikan edukasi menunjukkan bahwa ada pengaruh pemberian edukasi gizi kepada siswa terhadap perubahan pengetahuan gizi yang dimiliki oleh siswa. Hipotesis ini diperkuat oleh uji statistik Wilcoxon dimana nilai $p=0,000$. Hal ini disebabkan oleh siswa yang sudah memahami materi yang diberikan dan diterapkan dikehidupan sehari-hari.

Peningkatan pengetahuan tersebut diharapkan dapat memberikan perubahan yang bersifat baik jangka pendek maupun jangka panjang bagi siswa agar mereka mampu menerapkan perilaku hidup yang lebih sehat dengan pengetahuan tersebut. Hal ini juga telah dikemukakan oleh Johnson (2010), yaitu pendidikan gizi mempunyai tujuan jangka pendek dan tujuan jangka panjang.

Hasil penelitian pada sikap siswa yang sebelum diberikan edukasi sebagian besar kurang (4\%) dan sedang (64\%). Hal ini sejalan dengan penelitian yang dilakukan oleh Suryanti (2012) bahwa penerapan sikap gizi pada remaja di SMA Negeri 13 Makassar sebagian besar kurang $(57,9 \%)$. Hasil penelitian pada sikap siswa yang sesudah diberikan edukasi yaitu yang kurang menjadi $(0,4 \%)$, sedang $(34,8 \%)$ dan yang baik meningkat menjadi $(64,8 \%)$. Sikap siswa setelah diberikan edukasi menunjukkan bahwa ada ada pengaruh pemberian edukasi gizi kepada siswa terhadap perubahan sikap siswa. Hipotesis ini diperkuat oleh uji statistik Wilcoxon dimana nilai $p=0,000$. Hal ini disebabkan oleh siswa yang sudah memahami materi yang diberikan dan diterapkan dikehidupan sehari-hari.

Pengetahuan gizi yang kurang akan memberikan potensi masalah gizi bagi seseorang. Hal itu telah dikemukakan oleh Rosa (2011) dimana pengetahuan gizi yang kurang atau kurang menerapkan pengetahuan gizi dalam kehidupan seharihari dapat menimbulkan masalah gizi. Tujuan akhir dari pendidikan gizi yang diberikan kepada remaja menurut Proverawati dan Kusuma (2011), yakni dapat mengubah sikap dan tindakan kearah kesadaran untuk melakukan pemenuhan kebutuhan gizi agar hidupnya sehat.

\section{KESIMPULAN}

Tingkat pengetahuan gizi siswa kelas VII dan VIII SMP Negeri 1 Barru sebelum edukasi gizi yaitu baik $(60 \%)$ dan sesudah edukasi gizi meningkat menjadi baik $(80,4 \%)$. Sikap siswa kelas VII dan VIII SMP Negeri 1 Barru sebelum edukasi gizi yaitu baik (32\%) dan sesudah edukasi meningkat menjadi baik $(64,8 \%)$. Ada pengaruh yang bermakna edukasi gizi terhadap pengetahuan gizi pada siswa kelas VII dan VIII SMP Negeri 1 Barru ditunjukkan dengan nilai $p<0,05$. Adanya pengaruh yang bermakna edukasi gizi terhadap sikap siswa kelas VII dan VIII 
SMP Negeri 1 Barru ditunjukkan dengan nilai $p<0,05$.

\section{SARAN}

Bagi pihak sekolah perlu dilakukan pemberian edukasi gizi yang berkelanjutan sehingga dapat diperoleh perubahan baik dari segi pengetahuan dan sikap siswa. Bagi siswa disarankan agar selalu menerapkan pengetahuan gizi yang dimiliki dalam kehidupan sehari-hari. Sedangkan bagi peneliti dalam komunikasi perlu memanfaatkan media yang menarik agar sasaran bersemangat mengikuti kegiatan edukasi dengan warna dan gambar yang lebih menarik.

\section{DAFTAR PUSTAKA}

Almatsier, Sunita. (2010). Prinsip Dasar Ilmu Gizi. Jakarta; PT. Gramedia Pustaka Utama.

Arisman, MB. (2010). Gizi Dalam Daur Kehidupan. Jakarta; EGC.

Demitri, A. (2015). Pengaruh Pendidikan Gizi tentang Pola Makan Seimbang melalui Game Puzzle dan Gambar Animasi terhadap Peningkatan Pengetahuan Anak SDN 067690 kota Medan. Skripsi. Fakultas Kesehatan Masyarakat. Universitas Sumatera Utara; Medan.

Claire E orummound. (2010). Using Nutrition Education and Cooking Clasess in Primary Schools to Enourage Healthy Eating. Journal of Student Wellbeing. 4(2): 43-45.

Hatta. (2014). Asupan Energi dan Protein Siswa SMP Negeri 35 Makassar. Karya Tulis Ilmiah. Jurusan Gizi Politeknik Kesehatan Makassar.

Healthy People. (2010). Healthy People 2010 2nd edition with Understanding and Improving Health and Objectives for Improving Health. Volume 2. Halaman 33.

Hikmah, Nur. (2017). Pengaruh Edukasi Gizi Terhadap Pengetahuan Gizi dan Sikap Gizi Seimbang pada Siswa SMP Negeri 35 Makassar. Skripsi. Jurusan Gizi Politeknik Kesehatan Makassar.

Johnson DW. (2010). Nutrition Education: A Model for Effectiveness, A Synthesis of Research. Journal Nutrition Education. Volume 27. Halaman 235-246.

Marisa, Nuryanto. (2014). Pengaruh Pendidikan Gizi melalui Komik Gizi Seimbang Terhadap Pengetahuan dan Sikap pada Siswa SDN Bendungan di Semarang. Volume 3 Nomor 4. Halaman 926.

Nuryanto, dkk. (2014). Pengaruh Pendidikan Gizi Terhadap Pengetahuan dan Sikap Tentang Gizi Anak Sekolah Dasar. Halaman 33.

Proverawati, Atikah dan Kusuma, Erna Wati. (2011). Ilmu Gizi untuk Keperawatan \& Gizi Kesehatan. Yogyakarta; PT. Nuha Medika.

Rahman, Rahmiyati. (2017). Pengaruh Edukasi Gizi Terhadap Pengetahuan dan Kebiasaan Jajan pada Siswa SMP Negeri 35 Makassar. Skripsi. Jurusan Gizi Politeknik Kesehatan Makassar.

Suryani. (2012). Pengaruh Pendidikan Gizi Terhadap Pengetahuan dan Sikap Siswa SMA Negeri 13 Makassar. Skripsi. Jurusan Gizi Politeknik Kesehatan Makassar. 